\title{
En homenaje a Ernesto Cardenal
}

Acaba de fallecer Ernesto Cardenal, poeta nicaragüense que trascendió fronteras no sólo por la palabra sino por el ejemplo de dignidad y coraje a lo largo de toda la vida.

En 2008 y 2009 le dediqué estos poemas que lo definen como persona "faro" y que hoy "rescato" para rendir mi sentido homenaje:

"Que ni un instante

de tu intenso

desgranar

la vida

cada día se pierda

por el acoso de la voz

airada de unos pocos.

También

a ellos queremos

pero no podemos perder

en escucharles

ni un ápice

de nuestro tiempo.

Y sus amos sabrán

que los gritos

no alteran

tu pulso

ni tu paso". (2008)

"No escuches,

caminante,

las voces

que intentan

detenerte.
No dejes

que te atenace

la amenaza

que te acecha

ni te arredren

el tiempo hostil,

la oscuridad,

el viento fuerte.

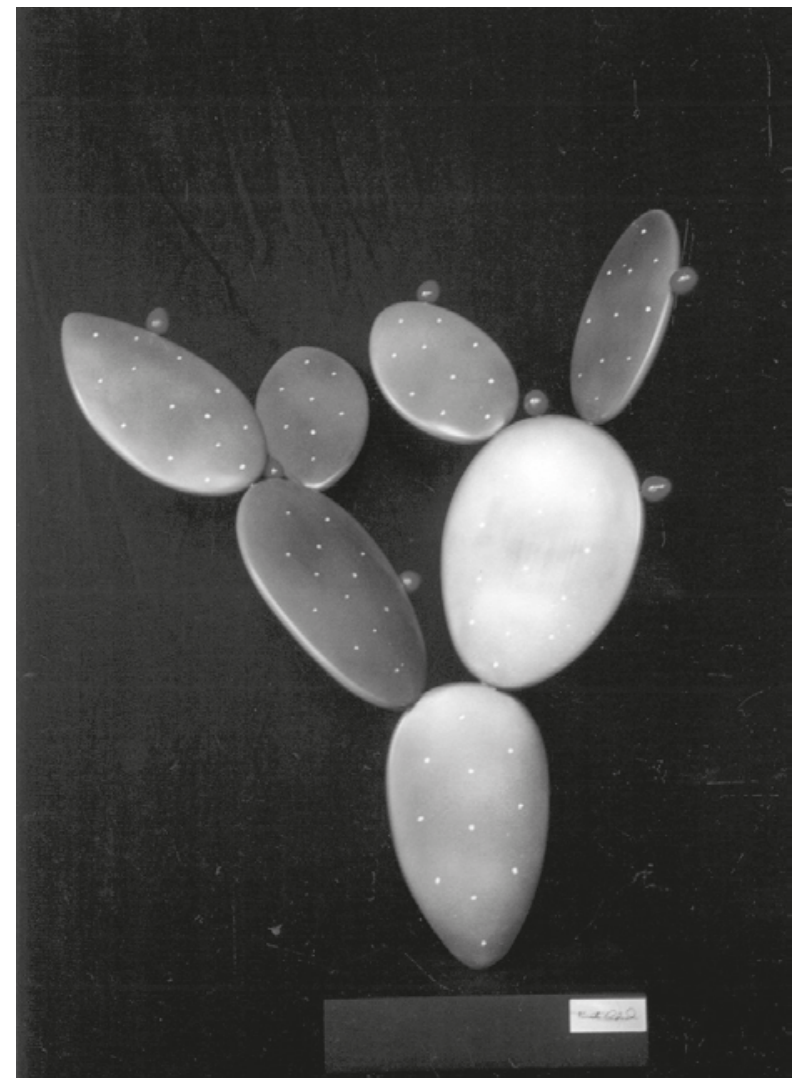

Autor: Ernesto Cardenal. Fotografía: Bondad de la Maestra Luz M. Acosta. Licencia Creative Commons Atribución-NoComercial-SinDerivadas 

No cejes
en tu esfuerzo
por avanzar
hacia el horizonte
de tus sueños
aunque se aleje
un paso
a cada paso...
Sigue, sigue
airosamente...
Lograrás
recorrer
un largo tramo
y así un día
no lejano
la utopía
será realidad
dando la mano
a muchos
viandantes

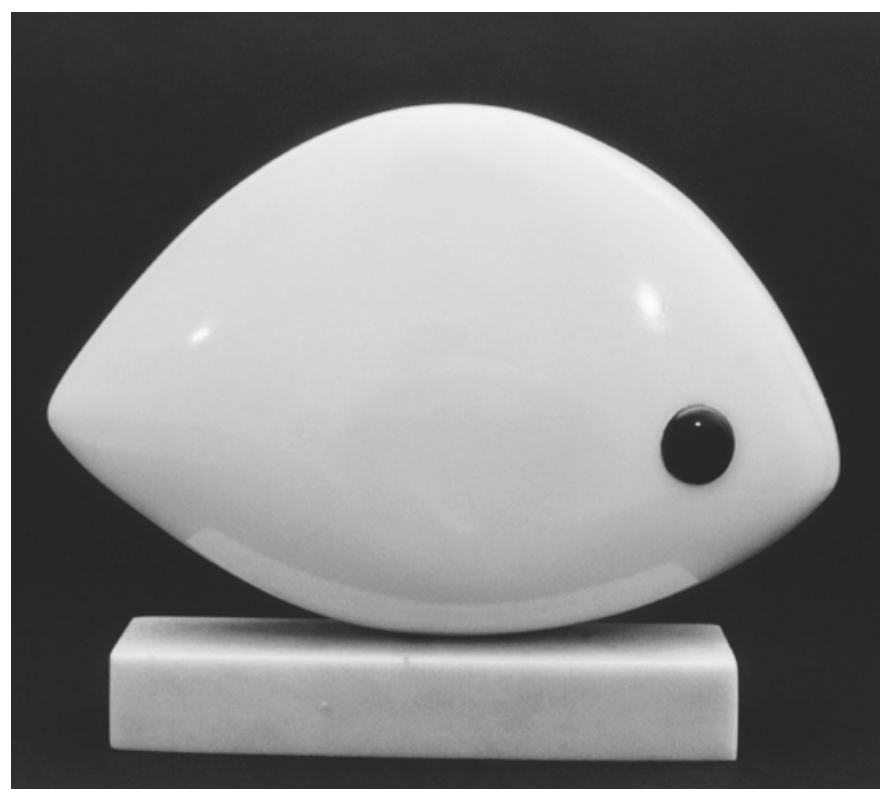

Autor: Ernesto Cardenal. Fotografía: Bondad de la Maestra Luz Marina Acosta. para ir juntos

hacia un mañana

menos frío

que el hoy

en que quisieron

verte aprisionado.

Sigue denodadamente

porque sólo el futuro

importa.

Las rodillas

son para alzarse

nunca para hincarse..." (2009)

Ernesto Cardenal desde siempre y, hasta el final, en pié de paz y en favor de la igual dignidad humana.

Federico Mayor Zaragoza

03 de marzo de 2020.

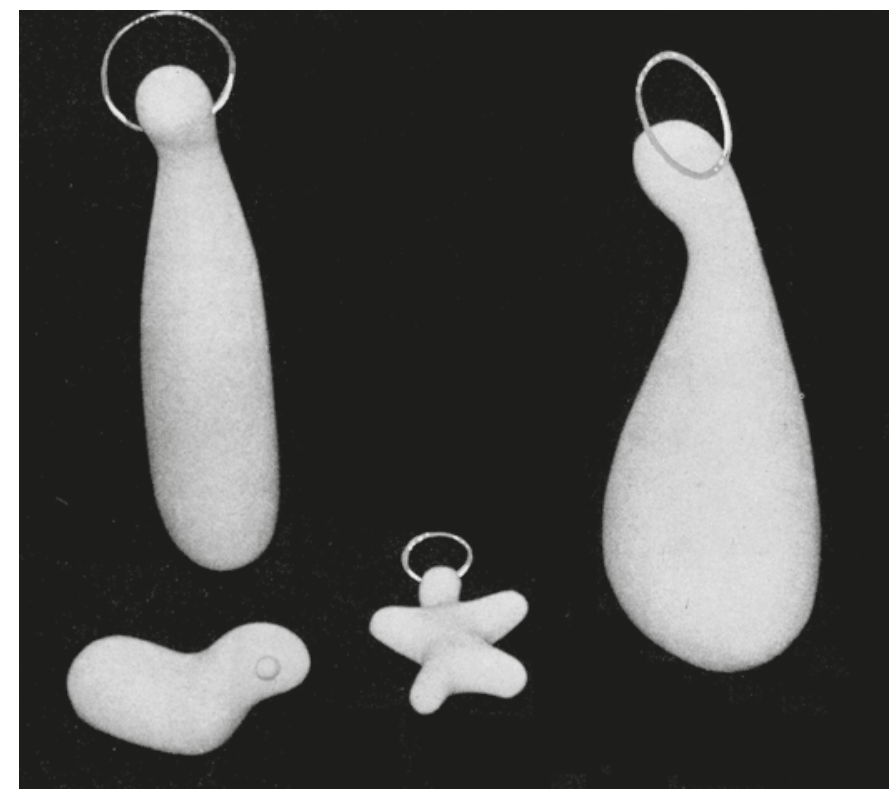

Autor: Ernesto Cardenal.Fotografía: Bondad de la Maestra Luz Marina Acosta. 